\title{
DIAMOND PRODUCTION AND DISCOVERIES OVER THE LAST FIFTEEN YEARS
}

\author{
JANSE AJA \\ archonexpl@iinet.net.au, \\ Archon Exploration Pty Ltd, 11 Rowsley Way, Carine, Western Australia 6020
}

Global annual diamond production has increased steadily since the discovery of diamonds hosted in kimberlite in 1871. The increase has not been regular, but shows distinct flat periods and dips, and sudden rises respectively caused by global economic hiccups and new discoveries, especially in Australia since 1985 and Canada since 1998.

Global annual rough diamond production rose from 123 Mct in 1997 , worth $\$ 8.3$ billion, to a peak of $176 \mathrm{Mct}$ in 2006, worth $\$ 12$ billion. Rough production had declined to $117 \mathrm{Mct}$, worth $\$ 8$ billion in 2000 because of a fall in production from Argyle due to reconstruction of the open pit, and rose again in 2002 due to the coming to market of the newly discovered Canadian deposits, and increases in production from Botswana and Russia. Because of the global financial crisis, global annual production dropped to $125 \mathrm{Mct}$ worth, $\$ 8.6$ billion in 2009 , but it recovered to 133 Mct, worth $\$ 12$ billion in 2010.

It is interesting to note that fluctuations in annual production of just one mine, Argyle, had such a strong effect on the total global annual production. Argyle's peak annual production was 43 Mct in 1994, which was $40 \%$ of global annual production. During reconstruction of the open pit from 1999 to 2002 it dropped to a level of $25 \mathrm{Mct} /$ $\mathrm{yr}$ and then recovered to an annual level of about 30 Mct which it maintained until 2006, the end of its planned 20-year life as an open pit. The underground mine had a planned production of
$15 \mathrm{Mct} / \mathrm{yr}$, but because of delays in construction, the life of the open pit was extended, mining lower grade ore at a level of $10 \mathrm{Mct} / \mathrm{yr}$ since 2006. The underground mine is planned to commence production by the end of 2012 and will last until the end of the present decade. The large open pit mines in Botswana (Orapa, Jwaneng), Canada (Ekati,Diavik), Russia (Mir, Udachnaya, Aikhal) and South Africa (Venetia) also have passed their peak production and also will change to underground operations during the 2010-2020 decade resulting in lower global production. Orapa's peak production was 18.7 Mct in 2007, for 2010 it was $9.5 \mathrm{Mct}$; Jwaneng's peak production was $15.6 \mathrm{Mct}$ in 2006, for 2010 it was 11.5 Mct; Ekati's peak was 7 Mct in 2003, for 2010 it was 3.5 Mct; Diavik's peak was 12 Mct in 2007, for 2010 it was $6.5 \mathrm{Mct}$; Venetia's peak was 9 Mct in 2007, for 2010 it was 4.3 Mct. Data on Russian mines are scarce. Most of the old Siberian mines have changed from open pit to underground operations. Their subsequent fall in production was compensated by the development of the new Jubileynaya and Nyurbinskaya mines in Siberia and the new Arkhangelskaya mine in northwestern Russia. Russia's peak production was close to 40 Mct in 2004 and has ranged between 34 Mct and 36 Mct since then.

During the past 15 years, 16 new mines entered full production, i.e. 2 in Botswana (Damtshaa, BK11), 5 in Canada (Ekati, Diavik, Jericho, Snap Lake, Victor), 2 in Angola (Catoca, 


\section{0 $^{\text {th }}$ International Kimberlite Conference, Bangalore - 2012}

Camafuca), 2 in South Africa (Voorspoed, SASA), 1 in Zimbabwe (Murowa), 2 in Australia (Merlin, Ellendale), 2 in Russia (Arkhangelskaya, Nyurbinskaya) of which 3 closed again, i.e. 1 in Botswana (Damtshaa), 1 in Canada (Jericho), and 1 in South Africa (SASA), while 3 mines closed and re-opened under new operators, i.e. 2 in South Africa (Kimberley mines, Koffiefontein) and 1 in Lesotho (Letseng), and 9 changed from open pit to underground operations, i.e. at least 6 in Siberia (Mir, International, Udachnaya, Aikhal, Zarnitsa, Sytykanskaya), 2 in Canada (Ekati, Diavik) and 1 in Australia (Argyle).

Increases in future global annual production will result from planned development of eleven advanced projects, i.e. the expansion of the large Lomonosov field in northwest Russia (Arkhangel region) and the development of the Upper Muna field (Siberia), three mines in Canada, Gahcho Kué (Northwest Territories), Star West (Saskatchewan) and Renard (Québec), three in Botswana, BK11, AK06 and GhaGhoo (formerly Gope), two in Lesotho, Kao and Liquobong, and one in South Africa, Lace, but all of these have been known for some time, and no new large kimberlite fields have been found in the last ten years, except for the recent discovery of several very small high grade pipes at Chidliak (Baffin Island, Nunavut) and the Bunder project in India. Not counting the last two yet, and if everything goes as planned, it is estimated that these new mines will produce $18 \mathrm{Mct} / \mathrm{yr}$ by 2015 , which hardly compensates for the decrease in production caused by the change of open pit to underground operations at Ekati, Diavik, Argyle, at least six Siberian mines and the closure of Damtshaa and SASA. The on-and off-shore operations of Namdeb probably will continue at the same rate, and no significant new development appears to be planned, so with increasing demand there will be a significant gap in supply and demand beyond 2015.

However, the discovery of large deposits of diamonds of detrital origin in rocks of
Precambrian and Paleozoic age, in paragneisses, schists, quartzites and metaconglomerates, may open up new areas for exploration. Commercial deposits of this nature have been known from a) Roraima (northern Brazil), Venezuela and Guyana, b) Minas Gerais (eastern Brazil), c) Ghana, and d) India. Total production to 2010 from a) may have been in the order of $10 \mathrm{Mct}$, from $\mathrm{b}$ ) about $50 \mathrm{Mct}$, from c) it was $110 \mathrm{Mct}$, and from d) it was low at $1 \mathrm{Mct}$, but generally of exceptional quality. Recent discoveries in Zimbabwe (Marange), Cameroon (Mogalong) and Wawa (Ontario, Canada) may boost global annual production in the future (which Zimbabwe already does). The Marange field was discovered by African Consolidated Resources in May 2006 but was quickly overrun by local workers and ACR was forced to withdraw. The diamonds are recovered from colluvial and alluvial debris, which is loose to slightly compacted red sand eroding from the Precambrian Umkondo conglomerate, about 1100 my in age. All one needs is a pick, a shovel and a sieve, and as grades can be as high as $40 \mathrm{cpt}$ locally, it is no wonder that the deposit was overrun by locals. Outcrops of this conglomerate and its diamondiferous debris were found in at least two other places further to the east, including one located in the Chimanimani Mountains on the border with Mozambique. The Zimbabwe army and police have taken over managing the operation which has led to complaints about brutality and massacres. The Zimbabwe government accepted applications from Anjin, a Chinese company and Ozgeo, a Russian company to participate in mining the Marange deposits. The KPCS data for Zimbabwe for 2010 give a production of $8.435 \mathrm{Mct}$, subtracting the $0.164 \mathrm{Mct}$ from Murowa, and some from River Ranch, this leaves well over 8 Mct as Marange's production.

A press release in June 2009 announced the discovery of a giant diamond resource of $736 \mathrm{Mct}$ located in the area where the borders of Cameroon, Central African Republic and DRCongo meet. The 
resource was found in late 2007/early 2008 by South Korean geologists working for C\&C Mining, based in Seoul, and the deposit will be developed by a joint venture, C\&K Mining Inc, in which the South Korean company will have $80 \%$ and the Cameroon government $20 \%$. According to the announcement, the diamonds occur in Precambrian metaconglomerates. Diamond mining was scheduled to commence in late 2009 and was planned at initially $1 \mathrm{Mc} / \mathrm{yr}$ rising to $6 \mathrm{Mct} / \mathrm{yr}$, but nothing has been heard about this venture lately. Lacking further details, mining analysts consider this a highly speculative and optimistic assessment and more basic data are necessary to give this venture credit.

Finally there is the Leadbetter deposit, located $12 \mathrm{~km}$ north east of Wawa in northern Ontario, where Dianor Resources found diamonds in ancient low grade metamorphic rocks representing former clastic sediments of Archaean age. Diamonds up to $1.39 \mathrm{ct}$ in size were found in a heterolithic volcaniclastic breccia (also called 'conglomerate' or 'debris flow breccia') which partly outcrops and may represent a body of 100 Mt at a grade of 30-50 cpht (say $40 \mathrm{Mct}$ ), which could be mined at a rate of $2 \mathrm{Mct} / \mathrm{yr}$ for 20 years.

In general, only the derived colluvial and alluvial deposits are developed for mining, as the original rock is too hard and tough, but future development in rock comminution may overcome this problem. So far only two areas in India, the Precambrian conglomerates east of Panna and at Banganapalle, are known where the hard rock was worked by hand tools to extract diamonds.

Despite the predicted shortage of rough in the future, the rising price of rough, and the scarcity of new discoveries, it is difficult at present to raise capital for grass roots diamond exploration, but there appears to be no problem in raising capital for the enlargement of existing mines. Also, share prices for junior diamond exploration companies are at an all time low as it appears that investors believe that the lead in time for diamond mines (period from discovery to mine) is too long, so they invest in shares in iron ore, uranium, copper, lithium and potash instead. 